\title{
KNOWLEDGE ON LYME DISEASE AMONG FORESTERS
}

PIOTR KURNATOWSKI ${ }^{1}$, MAŁGORZATA WARPECHOWSKA ${ }^{1}$, and ANNA J. KURNATOWSKA ${ }^{2}$

${ }^{1}$ Medical University, Łódź, Poland

Department of Biology and Medical Parasitology

${ }^{2}$ Medical University, Łódź, Poland

Department of Dental Surgery and Periodontology

\begin{abstract}
Objectives: The first aim was an attempt to evaluate the level of knowledge on Lyme disease among people whose profession involves working in the forest; the second - recognition of the health problems that should be included in health education programmes concerning Lyme disease in this group of professionals. Materials and Methods: The study was performed on 159 subjects. Results: Only 15\% know the etiological factor of disease, 98\% - the main cause of infection, and route of pathogen transmission. Conclusion: Propagation of knowledge on Lyme disease, particularly among risk group people, is not satisfactory. Little knowledge on tick risk among secondary school students indicate the necessity for cooperation between teachers, epidemiologists, and health service providers in order to propagate the knowledge on parasites, symptoms, spread and methods of prevention.
\end{abstract}

Key words:

Lyme disease, Knowledge, Foresters

\section{INTRODUCTION}

Lyme disease (borreliosis, tick-borne spirochaetosis) is a zoonosis, the most common tick-borne disease in the United States and also in Europe; it is emerging also in Canada. Spread of the infection with the spirochete Borrelia burgdorferi is inevitably associated with the presence of an etiological factor - a spirochete; the occurrence of a reservoir - infected animals; a vector - a tick belonging to the Ixodes genus; and a susceptible host — man, in whose organism the disease will develop. The best living conditions for ticks are forests with rich and moist undergrowth protecting against dryness, grown with alder and elder trees, and fern-covered places common at the border of forests, meadows, and pastures [1,2]. Therefore, people working in forests are particularly exposed to tick bites and Lyme disease.

The Centers for Disease Control and Prevention (CDC) establishes clinical and serological criteria to standardize surveillance for Lyme disease.

Confirmed Lyme disease is in a case:

- of erythema migrans (EM) with a known exposure (exposure is defined as having been less than or equal to 30 days before onset of EM, in wooded, brushy, or grassy areas in a country in which Lyme disease is endemic);

- of EM with laboratory evidence of infection and without a known exposure;

- with at least one late manifestation that has laboratory evidence of infection. 
- Probable Lyme disease is in any other case of physician-diagnosed Lyme disease that has laboratory evidence of infection.

Suspected Lyme disease is in a case:

- of EM where there is no known exposure and no laboratory evidence of infection;

- with laboratory evidence of infection but no clinical information available (e.g. a laboratory report) [3].

The aim of the study was:

- an attempt to evaluate the level of knowledge on Lyme disease among people whose profession involves working in the forest;

- identification of the health problems (sources, symptoms, diagnosis, and prophylaxis of the disease) that should be included in health education programmes concerning Lyme disease in this group of professionals.

\section{MATERIAL AND METHODS}

The study was performed at the turn of December 2008 and January 2009 basing on the author's own original anonymous questionnaire.

One hundred and fifty nine subjects (22 females and 137 males) participated in the study:

- National Forest staff of three forest district offices: Augustów - 50 subjects, Szczebra - 20, and Pomorze - 19; the majority of the questioned forest workers had less than 10-years' work experience. Among this group, $57.4 \%$ of responders had a higher education, $35.9 \%$ had secondary, and only $6.7 \%$ had primary education;

- 40 students (25.2\%) of the master's degree complementary studies (year II, Forestry) of the Warsaw University of Life Sciences (SGGW);

- 30 secondary school students (18.9\%) of grades I-IV of the Forest Technical Secondary School in Białowieża.
The material was analysed and the probability and standard deviation of choice of response were determined. Student's t-test was used to determine statistically significant differences; the critical level of statistical significance was set at $0.05(5 \%)$.

\section{RESULTS}

A source of information on Lyme disease for the respondents was most frequently a friend $(30.8 \pm 3.66 \%)$, a physician $(28.3 \pm 3.57 \%)$, and an occupational health and safety officer (27.6 $\pm 3.54 \%)$. Approximately $1 / 4$ of the subjects obtained the data on the disease from daily newspapers, the internet, and teachers/lecturers (Table 1).

Table 1 shows that the group of foresters most frequently acquired the knowledge from occupational health and safety officers $(33.7 \pm 5.01 \%)$ and physicians $(32.5 \pm 4.96 \%)$; the university students from the internet $(47.5 \pm 7.89 \%)$ and friends $(45.0 \pm 7.86 \%)$; whereas the secondary school students from teachers $(53.3 \pm 8.29 \%)$ and from the internet $(46.6 \pm 9.1 \%)$. The comparison of the study results (Student's t-test) between particular groups of respondents revealed differences on the border of significance between the foresters and the secondary school students, who reported medical journals as the source of information $(\mathrm{t}=2.0361)$, and between the foresters and the university students, who found information in leaflets at outpatient departments $(t=2.0459)$. Statistically significant differences $(p<0.001)$ were found between the foresters and the university students and secondary school students who obtained information from the internet $(t=4.5734$ and $t=3.9353$, respectively), the foresters and the university students and secondary school students informed by teachers/lecturers $(\mathrm{t}=3.1507, \mathrm{p}<0.01 ; \mathrm{t}=4.7105$, $p<0.001$, respectively), and the foresters and the secondary school students, for whom the source of information was an occupational health and safety officer $(\mathrm{t}=2.5637$, $\mathrm{p}<0.02)$. 
Table 1. Source of information about Lyme diseases

\begin{tabular}{|c|c|c|c|c|}
\hline \multirow{2}{*}{ Source of information } & \multicolumn{4}{|c|}{$\begin{array}{l}\text { Respondents } \\
\mathrm{n}(\% \pm \mathrm{SD})\end{array}$} \\
\hline & $\begin{array}{c}\text { national } \\
\text { forest staff }\end{array}$ & $\begin{array}{l}\text { university } \\
\text { students }\end{array}$ & $\begin{array}{l}\text { secondary school } \\
\text { students }\end{array}$ & total \\
\hline Daily newspapers & $\begin{array}{c}25 \\
(28.1 \pm 4.76)\end{array}$ & $\begin{array}{c}9 \\
(22.5 \pm 6.6)\end{array}$ & $\begin{array}{c}7 \\
(23.3 \pm 7.72)\end{array}$ & $\begin{array}{c}41 \\
(25.8 \pm 3.47)\end{array}$ \\
\hline Journals & $\begin{array}{c}17 \\
(19.1 \pm 4.16)\end{array}$ & $\begin{array}{c}8 \\
(20.0 \pm 6.32)\end{array}$ & $\begin{array}{c}3 \\
(10.0 \pm 5.47)\end{array}$ & $\begin{array}{c}28 \\
(17.6 \pm 3.02)\end{array}$ \\
\hline Medical journals & $\begin{array}{c}6 \\
(6.7 \pm 2.65)\end{array}$ & $\begin{array}{c}9 \\
(22.5 \pm 6.60)\end{array}$ & $\begin{array}{c}7 \\
(23.3 \pm 7.71)\end{array}$ & $\begin{array}{c}22 \\
(13.8 \pm 2.73)\end{array}$ \\
\hline Leaflets at outpatient departments & $\begin{array}{c}7 \\
(7.8 \pm 2.84)\end{array}$ & $\begin{array}{c}9 \\
(22.5 \pm 6.60)\end{array}$ & $\begin{array}{c}5 \\
(16.6 \pm 6.79)\end{array}$ & $\begin{array}{c}21 \\
(13.2 \pm 2.68)\end{array}$ \\
\hline Internet & $\begin{array}{c}8 \\
(8.9 \pm 3.01)\end{array}$ & $\begin{array}{c}19 \\
(47.5 \pm 7.89)\end{array}$ & $\begin{array}{c}14 \\
(46.6 \pm 9.1)\end{array}$ & $\begin{array}{c}41 \\
(25.7 \pm 3.47)\end{array}$ \\
\hline Teachers/lecturers & $\begin{array}{c}10 \\
(11.2 \pm 3.34)\end{array}$ & $\begin{array}{c}15 \\
(37.5 \pm 7.65)\end{array}$ & $\begin{array}{c}16 \\
(53.3 \pm 8.29)\end{array}$ & $\begin{array}{c}41 \\
(25.7 \pm 3.47)\end{array}$ \\
\hline Safety officers & $\begin{array}{c}30 \\
(33.7 \pm 5.01)\end{array}$ & $\begin{array}{c}10 \\
(25.0 \pm 6.84)\end{array}$ & $\begin{array}{c}4 \\
(13.3 \pm 6.19)\end{array}$ & $\begin{array}{c}44 \\
(27.6 \pm 3.54)\end{array}$ \\
\hline Physicians & $\begin{array}{c}29 \\
(32.5 \pm 4.96)\end{array}$ & $\begin{array}{c}10 \\
(25.0 \pm 6.84)\end{array}$ & $\begin{array}{c}6 \\
(20.0 \pm 7.3)\end{array}$ & $\begin{array}{c}45 \\
(28.3 \pm 3.57)\end{array}$ \\
\hline Nurses & $\begin{array}{c}9 \\
(10.1 \pm 3.19)\end{array}$ & 0 & $\begin{array}{c}3 \\
(10.0 \pm 5.47)\end{array}$ & $\begin{array}{c}12 \\
(7.5 \pm 2.08)\end{array}$ \\
\hline Friends & $\begin{array}{c}24 \\
(26.9 \pm 4.7)\end{array}$ & $\begin{array}{c}18 \\
(45.0 \pm 7.86)\end{array}$ & $\begin{array}{c}7 \\
(23.3 \pm 7.71) \\
\end{array}$ & $\begin{array}{c}49 \\
(30.8 \pm 3.66) \\
\end{array}$ \\
\hline
\end{tabular}

$\mathrm{SD}-$ standard deviation.

Four fifths of the foresters $(88.7 \pm 3.35 \%)$ and the university students $(80 \pm 6.32 \%)$, as well as $3 / 5$ of the secondary school students $(56.6 \pm 9.04 \%)$ knew that the number of Lyme disease was increasing in Poland; whereas only $12.5( \pm 5.22) \%$ of the university students and $20( \pm 7.30) \%$ of the secondary school students believed that the incidence rate had diminished recently (Table 2).

The Student's t-test demonstrated that there were statistically significant differences between the foresters and the secondary school students $(\mathrm{t}=33295, \mathrm{p}<0.001)$, and the university students and the secondary school students $(\mathrm{t}=2.1757, \mathrm{p}<0.05)$, who thought that the number of Lyme diseases cases had increased over the recent years. The data in Table 2 indicate that nearly $4 / 5$ of the interviewed subjects $(77.9 \pm 3.29 \%)$ regarded the Podlasie and nearly 1/2 (46.5 $\pm 3.95 \%)$ - Warmia and Mazury Provinces as an endemic area for tick-borne spirochaetosis. Moreover, $1.12( \pm 1.11) \%$ of the foresters, $17.5( \pm 6.0) \%$ of the university students, and $6.6( \pm 4.53) \%$ of the secondary school students classified the Western Pomerania Province as endemic regions. A total of $10.0( \pm 4.74) \%$ of the university students, $7.8( \pm 2.84) \%$ of the foresters and $6.6( \pm 4.53) \%$ of the secondary school students regarded the Podkarpacie Province as a risk region. No one of the survey groups quoted the Małopolska Province; in the group of foresters and the secondary school students nobody remembered about the Mazovia Province and in the group of the university students and the secondary school 
Table 2. Prevalence of Lyme disease and endemic area in Poland

\begin{tabular}{|c|c|c|c|c|}
\hline \multirow{2}{*}{ Prevalence of Lyme disease } & \multicolumn{4}{|c|}{$\begin{array}{c}\text { Respondents } \\
\mathrm{n}(\% \pm \mathrm{SD})\end{array}$} \\
\hline & $\begin{array}{c}\text { national } \\
\text { forest staff }\end{array}$ & $\begin{array}{c}\text { university } \\
\text { students }\end{array}$ & $\begin{array}{l}\text { secondary school } \\
\text { students }\end{array}$ & total \\
\hline Increasing & $\begin{array}{c}79 \\
(88.7 \pm 3.35\end{array}$ & $\begin{array}{c}32 \\
(80.0 \pm 6.32)\end{array}$ & $\begin{array}{c}17 \\
(56.6 \pm 9.04)\end{array}$ & $\begin{array}{c}128 \\
(80.5 \pm 3.14)\end{array}$ \\
\hline Decreasing & 0 & $\begin{array}{c}5 \\
(12.5 \pm 5.22)\end{array}$ & $\begin{array}{c}6 \\
(20.0 \pm 7.30)\end{array}$ & $\begin{array}{c}11 \\
(6.9 \pm 2.00)\end{array}$ \\
\hline On constant level & $\begin{array}{c}10 \\
(11.2 \pm 3.34)\end{array}$ & $\begin{array}{c}3 \\
(7.5 \pm 4.16)\end{array}$ & $\begin{array}{c}7 \\
(23.3 \pm 7.71)\end{array}$ & $\begin{array}{c}19 \\
(11.9 \pm 2.56)\end{array}$ \\
\hline \multicolumn{5}{|l|}{ Endemic areas } \\
\hline Podlasie Province & $\begin{array}{c}82 \\
(92.1 \pm 2.85)\end{array}$ & $\begin{array}{c}22 \\
(55.0 \pm 7.86)\end{array}$ & $\begin{array}{c}20 \\
(66.6 \pm 8.61)\end{array}$ & $\begin{array}{c}124 \\
(77.9 \pm 3.29)\end{array}$ \\
\hline Mazovia Province & 0 & $\begin{array}{c}2 \\
(5.0 \pm 3.44)\end{array}$ & 0 & $\begin{array}{c}2 \\
(1.25 \pm 0.88)\end{array}$ \\
\hline Warmia and Mazury Province & $\begin{array}{c}37 \\
(41.5 \pm 5.22)\end{array}$ & $\begin{array}{c}20 \\
(50.0 \pm 7.90)\end{array}$ & $\begin{array}{c}17 \\
(56.6 \pm 9.04)\end{array}$ & $\begin{array}{c}74 \\
(46.5 \pm 3.95)\end{array}$ \\
\hline Lower Silesia Province & $\begin{array}{c}1 \\
(1.12 \pm 1.11)\end{array}$ & $\begin{array}{c}2 \\
(5.0 \pm 3.44)\end{array}$ & 0 & $\begin{array}{c}3 \\
(1.88 \pm 1.07)\end{array}$ \\
\hline Kujawy and Pomerania Province & 0 & $\begin{array}{c}6 \\
(15.0 \pm 5.64)\end{array}$ & $\begin{array}{c}1 \\
(3.33 \pm 3.27)\end{array}$ & $\begin{array}{c}7 \\
(4.4 \pm 1.62)\end{array}$ \\
\hline Podkarpacie Province & $\begin{array}{c}7 \\
(7.8 \pm 2.84)\end{array}$ & $\begin{array}{c}4 \\
(10.0 \pm 4.74)\end{array}$ & $\begin{array}{c}2 \\
(6.6 \pm 4.53)\end{array}$ & $\begin{array}{c}13 \\
(8.17 \pm 2.17)\end{array}$ \\
\hline Silesia Province & $\begin{array}{c}4 \\
(4.49 \pm 2.19)\end{array}$ & 0 & 0 & $\begin{array}{c}4 \\
(2.51 \pm 1.24)\end{array}$ \\
\hline Western Pomerania Province & $\begin{array}{c}1 \\
(1.12 \pm 1.11)\end{array}$ & $\begin{array}{c}7 \\
(17.5 \pm 6.00)\end{array}$ & $\begin{array}{c}2 \\
(6.6 \pm 4.53)\end{array}$ & $\begin{array}{c}10 \\
(6.28 \pm 1.92)\end{array}$ \\
\hline
\end{tabular}

students about the Silesia Province. Ticks were considered an etiological factor by nearly $2 / 3(64.7 \pm 3.7 \%)$ of all respondents, and parasites by $1.25( \pm 0.88) \%$ (Table 3 ).

Table 3 shows that $11.2( \pm 3.34) \%$ of the foresters, $30( \pm 7.24) \%$ of the university students and $10( \pm 5.47) \%$ of the secondary school students thought that bacteria were the main pathogen causing Lyme disease. As many as $16.8( \pm 3.96) \%$ of the foresters and $35( \pm 7.54) \%$ of the university students stated that viruses were the etiological factor of Lyme disease. The comparison of the study results (Student's t-test) between particular groups of respondents revealed statistically significant differences between the foresters and the university students $(\mathrm{t}=3.8324$, $\mathrm{p}<0.001)$, the university students and the secondary school students $(\mathrm{t}=5.9044, \mathrm{p}<0.001)$, and the foresters and the secondary school students $(\mathrm{t}=2.7857, \mathrm{p}<0.01)$ who believed that the tick was the etiological factor of Lyme disease. The statistically significant differences $(\mathrm{p}<0.05$ ) were shown by comparing the foresters with the university students and the secondary school students in whose opinion it was bacteria that induced Lyme disease $(t=2.1056$ and $t=2.2041$, respectively $)$.

Among the whole population of the subjects surveyed, only $55.0( \pm 3.94) \%$ reported that arthropods were 
Table 3. The etiological factor and reservoir of Lyme disease

\begin{tabular}{lcccc}
\hline & \multicolumn{4}{c}{$\begin{array}{c}\text { Respondents } \\
\text { n }(\% \pm \text { SD })\end{array}$} \\
\cline { 2 - 4 } & The etiological factor & \multicolumn{4}{c}{ national forest staff } & university students & $\begin{array}{c}\text { secondary school } \\
\text { students }\end{array}$ & total \\
\hline Ticks & 62 & 14 & 27 & 103 \\
Viruses & $(69.6 \pm 4.87)$ & $(35.0 \pm 7.54)$ & $(90.0 \pm 5.47)$ & $(64.7 \pm 3.79)$ \\
& 15 & 14 & 0 & 29 \\
Bacteria & $(16.8 \pm 3.96)$ & $(35.0 \pm 7.54)$ & & $(18.2 \pm 3.05)$ \\
Parasites & 10 & 12 & 3 & 25 \\
& $(11.2 \pm 3.34)$ & $(30.0 \pm 7.24)$ & $(10.0 \pm 5.47)$ & $(15.7 \pm 2.88)$ \\
Reservoir & 2 & 0 & 0 & 2 \\
arthropods & $(2.24 \pm 1.56)$ & & & $(1.25 \pm 0.88)$ \\
reptiles & & & & 88 \\
birds & 51 & 17 & 20 & $(55.3 \pm 3.94)$ \\
& $(57.3 \pm 5.24)$ & $(42.5 \pm 7.81)$ & $(66.6 \pm 8.61)$ & 2 \\
rodents & 0 & 1 & 1 & $(1.25 \pm 0.88)$ \\
deer & & $(1.16 \pm 1.12)$ & $(3.33 \pm 3.27)$ & 18 \\
& $(13.4 \pm 3.06)$ & $(6.74 \pm 3.96)$ & 0 & $(11.3 \pm 2.51)$ \\
\hline
\end{tabular}

a reservoir of the spirochete Borrelia burgdorferi and as many as $44.9( \pm 3.93) \%$ that it was deer. Only $1.12( \pm 1.16) \%$ of the university students and $3.33( \pm 3.93) \%$ of the secondary school students chose reptiles as a reservoir of the pathogen; moreover $13.0( \pm 3.03) \%$ of the foresters and $6.74( \pm 3.96) \%$ of the secondary school students considered birds as a reservoir of bacteria. Table 3 presents all collected data on this subject. The Student's t-test showed that there were statistically significant differences between the foresters and the university students $(\mathrm{t}=2.2482$, $\mathrm{p}<0.05)$, the foresters and the secondary school students $(\mathrm{t}=2.8889, \mathrm{p}<0.01)$, and the university students and the secondary school students $(t=2.0732$, $p<0.05$ ), in whose opinion deer were a reservoir of the spirochete Borrelia burgdorferii.
A total of $98.8( \pm 1.15) \%$ of the foresters, $96.6( \pm 3.30) \%$ of the secondary school students, and $100 \%$ of the university students stated that a tick bite was the most frequent cause of Lyme disease infection. Only $3.77( \pm 1.51) \%$ of all questioned subjects thought that the disease could be contracted by eating mammalian meat, and $1.25( \pm 0.88) \%$ by eating unwashed fruit or vegetables contaminated with animal excrements.

According to $90.0( \pm 5.47) \%$ of secondary school students, $96.6( \pm 1.92) \%$ of the foresters and $100 \%$ of the university students blood was the main route of Borrelia burgdorferi infection. For $3.37( \pm 1.91) \%$ of the foresters and $10.0( \pm 5.57) \%$ of the secondary school students this was the alimentary route.

As results from the obtained data, the course of Lyme disease was chronic - this opinion was shared by more than 
Tabela 4. Symptoms of disease

\begin{tabular}{|c|c|c|c|c|}
\hline \multirow{2}{*}{ Symptoms } & \multicolumn{4}{|c|}{$\begin{array}{l}\text { Respondents } \\
\mathrm{n}(\% \pm \mathrm{SD})\end{array}$} \\
\hline & $\begin{array}{l}\text { national } \\
\text { forest staff }\end{array}$ & $\begin{array}{l}\text { university } \\
\text { students }\end{array}$ & $\begin{array}{c}\text { secondary } \\
\text { school students }\end{array}$ & total \\
\hline \multicolumn{5}{|l|}{ First symptoms } \\
\hline painful rash & $\begin{array}{c}34 \\
(38.2 \pm 5.15)\end{array}$ & $\begin{array}{c}14 \\
(35.0 \pm 7.54)\end{array}$ & $\begin{array}{c}5 \\
(16.6 \pm 6.79)\end{array}$ & $\begin{array}{c}53 \\
(33.3 \pm 3.73)\end{array}$ \\
\hline fever & $\begin{array}{c}54 \\
(60.6 \pm 5.17)\end{array}$ & $\begin{array}{c}26 \\
(65.0 \pm 7.54)\end{array}$ & $\begin{array}{c}24 \\
(80.0 \pm 7.3)\end{array}$ & $\begin{array}{c}104 \\
(65.4 \pm 3.77)\end{array}$ \\
\hline diarrhoea & $\begin{array}{c}1 \\
(1.12 \pm 1.11)\end{array}$ & 0 & 0 & $\begin{array}{c}1 \\
(0.62 \pm 0.62)\end{array}$ \\
\hline dyspnoea & $\begin{array}{c}1 \\
(1.12 \pm 1.11)\end{array}$ & 0 & 0 & $\begin{array}{c}1 \\
(0.62 \pm 0,62\end{array}$ \\
\hline vision disturbances & $\begin{array}{c}2 \\
(2.24 \pm 1.56)\end{array}$ & $\begin{array}{c}3 \\
(7.5 \pm 4.16)\end{array}$ & $\begin{array}{c}4 \\
(13.3 \pm 6.19)\end{array}$ & $\begin{array}{c}9 \\
(5.66 \pm 1.83)\end{array}$ \\
\hline \multicolumn{5}{|l|}{ Later symptoms } \\
\hline cystitis & 0 & 0 & $\begin{array}{c}1 \\
(3.33 \pm 3.27)\end{array}$ & $\begin{array}{c}1 \\
(0.6 \pm 0.6)\end{array}$ \\
\hline hallucination & $\begin{array}{c}4 \\
(4.49 \pm 2.19)\end{array}$ & $\begin{array}{c}3 \\
(7.5 \pm 4.16)\end{array}$ & $\begin{array}{c}2 \\
(6.6 \pm 4.53)\end{array}$ & $\begin{array}{c}9 \\
(5.6 \pm 1.82)\end{array}$ \\
\hline myalgia & $\begin{array}{c}71 \\
(79.7 \pm 4.26)\end{array}$ & $\begin{array}{c}32 \\
(80.0 \pm 6.32)\end{array}$ & $\begin{array}{c}16 \\
(53.3 \pm 8.25)\end{array}$ & $\begin{array}{c}119 \\
(74.8 \pm 3.44)\end{array}$ \\
\hline headaches & $\begin{array}{c}45 \\
(50.5 \pm 5.29)\end{array}$ & $\begin{array}{c}18 \\
(45.0 \pm 7.86)\end{array}$ & $\begin{array}{c}15 \\
(50.0 \pm 9.12)\end{array}$ & $\begin{array}{c}78 \\
(49.0 \pm 3.96)\end{array}$ \\
\hline hepatomegaly & $\begin{array}{c}7 \\
(7.8 \pm 2.84)\end{array}$ & $\begin{array}{c}2 \\
(5.0 \pm 3.44)\end{array}$ & $\begin{array}{c}2 \\
(6.6 \pm 4.53)\end{array}$ & $\begin{array}{c}11 \\
(6.9 \pm 2.01)\end{array}$ \\
\hline arthritis & $\begin{array}{c}59 \\
(66.2 \pm 5.0)\end{array}$ & $\begin{array}{c}34 \\
(85.0 \pm 5.64)\end{array}$ & $\begin{array}{c}10 \\
(33.3 \pm 8.6)\end{array}$ & $\begin{array}{c}103 \\
(64.7 \pm 3.79)\end{array}$ \\
\hline myocarditis & $\begin{array}{c}20 \\
(22.4 \pm 4.41)\end{array}$ & $\begin{array}{c}16 \\
(40.0 \pm 7.74)\end{array}$ & $\begin{array}{c}2 \\
(6.6 \pm 4.53)\end{array}$ & $\begin{array}{c}38 \\
(28.8 \pm 3.37)\end{array}$ \\
\hline rheumatoid lesions & $\begin{array}{c}46 \\
(51.6 \pm 5.29)\end{array}$ & $\begin{array}{c}19 \\
(47.5 \pm 7.89)\end{array}$ & $\begin{array}{c}1 \\
(3.3 \pm 3.27)\end{array}$ & $\begin{array}{c}66 \\
(41.5 \pm 3.9)\end{array}$ \\
\hline blindness & $\begin{array}{c}5 \\
(5.6 \pm 2.43)\end{array}$ & $\begin{array}{c}4 \\
(10.0 \pm 4.74)\end{array}$ & $\begin{array}{c}1 \\
(3.3 \pm 3.27)\end{array}$ & $\begin{array}{c}10 \\
(6.2 \pm 1.91)\end{array}$ \\
\hline vommiting & $\begin{array}{c}5 \\
(5.6 \pm 2.43)\end{array}$ & $\begin{array}{c}3 \\
(7.5 \pm 4.16)\end{array}$ & $\begin{array}{c}11 \\
(36.6 \pm 8.79)\end{array}$ & $\begin{array}{c}19 \\
(11.9 \pm 2.56)\end{array}$ \\
\hline nausea & $\begin{array}{c}4 \\
(4.4 \pm 2.19)\end{array}$ & $\begin{array}{c}6 \\
(15.0 \pm 5.64)\end{array}$ & $\begin{array}{c}7 \\
(23.3 \pm 7.72)\end{array}$ & $\begin{array}{c}17 \\
(10.6 \pm 2.44)\end{array}$ \\
\hline problems with sleep & $\begin{array}{c}15 \\
(16.8 \pm 3.96)\end{array}$ & $\begin{array}{c}9 \\
(22.5 \pm 6.6)\end{array}$ & $\begin{array}{c}4 \\
(13.3 \pm 6.19)\end{array}$ & $\begin{array}{c}28 \\
(17.6 \pm 3.02)\end{array}$ \\
\hline dyspnoea & $\begin{array}{c}3 \\
(3.37 \pm 1.91)\end{array}$ & $\begin{array}{c}4 \\
(10.0 \pm 4.74)\end{array}$ & $\begin{array}{c}4 \\
(13.3 \pm 6.19)\end{array}$ & $\begin{array}{c}11 \\
(6.9 \pm 2.01)\end{array}$ \\
\hline
\end{tabular}


half of the respondents $(59.9 \pm 3.93 \%) ; 44.0( \pm 3.93) \%$ of all the subjects thought the disease course could be both chronic and acute. Nobody reported that the disease is acute.

In the opinion of $2 / 3(65.4 \pm 3.77 \%)$ of all respondents, fever was the first symptom of Lyme disease, whereas for the $1 / 3(33.3 \pm 3.73) \%$ - painful rash. Diarrhoea and dyspnoea as the first symptoms of the disease were reported only by $0.62( \pm 0.62) \%$ of all respondents (Table 4$)$.

A statistically significant difference $(\mathrm{p}<0.01)$ was found while comparing the group of the foresters and the university students, according to whom painful rash was the first manifestation of tick-borne spirochaetosis $(\mathrm{t}=4.5734)$. Apart from fever and erythema migrans, the majority of the subjects considered myalgia $(74.8 \pm 3.44 \%)$, arthritis $(64.7 \pm 3.79 \%)$, headaches $(49.0 \pm 3.96 \%)$, and rheumatoid lesions $(41.5 \pm 3.9 \%)$ as the symptoms of Lyme disease. Precise data are shown in Table 4. As results from Table $4,40.0( \pm 7.74) \%$ of the university students regarded myocarditis and $22.5( \pm 6.6) \%$ problems with sleep as symptoms characteristic of the disease, whereas for the secondary school students this was vomiting $36.6( \pm 8.79) \%$ and nausea $23.3( \pm 7.72) \%$. Using the Student's t-test, it was shown that there were statistically significant differences between the foresters and the university students $(\mathrm{t}=2.4943 ; \mathrm{p}<0.02)$, the foresters and the secondary school students $(\mathrm{t}=3.3072 ; \mathrm{p}<0.01)$, and the university students and the secondary school students $(t=5.0270$; $p<0.001$ ), who considered arthritis as a symptom of Lyme disease. Moreover, significant differences were also observed between the foresters and the secondary school students, as well as the university students and the secondary school students, who regarded myocarditis to be a symptom of Lyme disease $(t=2.4992 ; \mathrm{p}<0.05$ and $t=3.7243$; $\mathrm{p}<0.01$ ); significant differences were also found between the foresters and the secondary school students, and the university students and the secondary school students who classified rheumatoid lesions among the disease symptoms $(\mathrm{p}<0.001, \mathrm{t}=7.7663$ and $\mathrm{t}=5.1752$, respectively). The comparison of results for the foresters and the secondary school students, and the university students and the secondary school students demonstrated statistically significant differences ( $p<0.02 ; p<0.01$, respectively) concerning vomiting $(t=3.4095 ; t=2.9924)$ as a symptom of the disease. The significant difference was also found between the university students and the secondary school students who treated myalgia as a manifestation of the disease $(t=2.5692 ; p<0.02)$.

Approximately $1 / 2$ of the secondary school students $(50.0 \pm 9.12 \%)$ and the university students $(55,0 \pm 7.86 \%)$ reported that erythema migrans lesions persisted for the first week after a tick-bite, whereas $59.5( \pm 5.20) \%$ of the foresters thought that the period of lesion duration was $2-4$ weeks. Only $1 / 10(9.4 \pm 2.31 \%)$ of the respondents mentioned the period of the first 24 hours (Table 5).

The comparison of the results between the survey groups by means of the Student's t-test revealed statistically significant differences between the foresters and the university students $(\mathrm{t}=2.6701 ; \mathrm{p}<0.01)$, as well as between the foresters and the secondary school students $(\mathrm{t}=3.4300 ; \mathrm{p}<0.001)$ as regards erythema migrans duration for 2-4 weeks. In the opinion of more than half of the foresters $(52.8 \pm 5.29 \%)$ and the university students $(60.0 \pm 7.74 \%)$, secondary symptoms of Lyme disease appeared after 2 years, whereas more than $1 / 5$ of both groups (21-23\%) reported that they occurred after 1 year. In the group of the secondary school students, about $1 / 3$ of the respondents chose the following answers: after 1 month $(33.3 \pm 8.6 \%)$, and after 2 years $(30.0 \pm 8.36 \%)$. The most rarely chosen option was a period of 2 and 3 months, which was indicated only by $3.77( \pm 1.51) \%$ of all interviewed subjects. The data are presented in Table 5. Statistically significant differences $(p<0.02)$ were demonstrated to occur when comparing the foresters with the secondary school students, and the university students with the secondary school students who thought that 
Table 5. Persistence of erythema migrans lesion and the time when secondary symptoms appear

\begin{tabular}{lcccc}
\hline \multirow{2}{*}{ Persistence of erythema migrans lesion } & \multicolumn{4}{c}{$\begin{array}{c}\text { Respondents } \\
n(\% \pm \text { SD })\end{array}$} \\
\cline { 2 - 5 } & national forest staff & university students & $\begin{array}{c}\text { secondary school } \\
\text { students }\end{array}$ & total \\
\hline First day & 4 & 4 & 7 & 15 \\
First week & $(4.49 \pm 2.19)$ & $(10.0 \pm 4.74)$ & $(23.3 \pm 7.71)$ & $(9.4 \pm 2.31)$ \\
& 32 & 22 & 15 & 69 \\
2-4 weeks & $(35.9 \pm 5.08)$ & $(55.0 \pm 7.86)$ & $(50.0 \pm 9.12)$ & $(43.3 \pm 3.92)$ \\
The time when secondary symptoms appear & 53 & 14 & 8 & 75 \\
first month & $(59.5 \pm 5.20)$ & $(35.0 \pm 7.56)$ & $(26.6 \pm 8.06)$ & $(47.1 \pm 3.95)$ \\
second month & & & & 21 \\
third month & $(10.1 \pm 3.19)$ & $(5.0 \pm 3.44)$ & $(33.3 \pm 8.6)$ & $(13.2 \pm 2.68)$ \\
sixth month & 0 & 0 & 6 & 6 \\
one year & & & $(20.0 \pm 7.3$ & $(3.77 \pm 1.51$ \\
& $(4.49 \pm 2.19)$ & $(5.0 \pm 3.44)$ & 0 & 6 \\
two years & 10 & 2 & & $(3.77 \pm 1.51)$ \\
& $(11.2 \pm 3.34)$ & $(5.0 \pm 3.44)$ & $(6.6 \pm 4.53)$ & $(8.8 \pm 2.24)$ \\
\hline
\end{tabular}

secondary symptoms of the disease occurred after 2 years $(\mathrm{t}=2.3046$ and $\mathrm{t}=2.6332)$, as well as the foresters with the secondary school students $(\mathrm{t}=2.5293 ; \mathrm{p}<0.02)$, and the university students with the secondary school students $(\mathrm{t}=3.3256 ; \mathrm{p}<0.01)$ who reported that they appeared after one month.

Checking the body for ticks is the most important prophylactic measure that protects against the infection; this opinion was shared by more than $4 / 5$ of the foresters $(83.1 \pm 3.97 \%)$ and the university students $(87.5 \pm 5.22 \%)$, and $2 / 3(66.6 \pm 8.1 \%)$ of the secondary school students. The second prophylactic measure reported by them was wearing proper shoes and protective clothes $(68.5 \pm 3.68 \%)$, and then removing the attached ticks within the first 24 hours $(51.5 \pm 3.96 \%)$ as well as using tick or insect repellents $(44.0 \pm 3.93 \%)$. A small number of the respondents $(5.6 \pm 1.82 \%)$ chose tick removal by means of alcohol or olive oil as a preventive measure (Table 6). Statistically significant differences were disclosed ( $p<0.01$ ) by comparing the group of the foresters with the university students, who treated tick or insect repellents as prophylaxis $(\mathrm{t}=2.8966)$. Moreover, there were also significant differences between the university students and the secondary school students $(\mathrm{t}=2.0021 ; \mathrm{p}<0.05)$ in using protective shoes and clothes as the prophylactic measure.

Among the diagnostic methods, the highest number of subjects $(43.8 \pm 5.25 \%$ of the foresters; $62.5 \pm 7.65$ of the university students and $23.3 \pm 7.72 \%$ of the secondary school students) mentioned the ELISA test, considerably less chose the blood cell count with smear $(22.4 \pm 4.41 \%$ of the foresters; $27.5 \pm 7.06 \%$ of the 
Table 6. Prophylactics of Lyme disease

\begin{tabular}{lcccc}
\hline & \multicolumn{4}{c}{$\begin{array}{c}\text { Respondents } \\
\text { n }(\% \pm \text { SD })\end{array}$} \\
\cline { 2 - 4 } \multicolumn{1}{c}{ Prophylactic measure } & $\begin{array}{c}\text { national } \\
\text { forest staff }\end{array}$ & $\begin{array}{c}\text { university } \\
\text { students }\end{array}$ & $\begin{array}{c}\text { secondary } \\
\text { school students }\end{array}$ & total \\
\hline Proper shoes and protective clothes & 57 & 35 & 17 & 109 \\
& $(64.0 \pm 5.07)$ & $(87.5 \pm 5.22)$ & $(56.6 \pm 9.04)$ & $(68.5 \pm 3.68)$ \\
Removing the ticks within the first 24 hours & 46 & 24 & 12 & 82 \\
& $(51.6 \pm 5.29)$ & $(60.0 \pm 7.74)$ & $(40.0 \pm 8.94)$ & $(51.5 \pm 3.96)$ \\
Repellents & 32 & 25 & 13 & 70 \\
Tick removal & $(35.9 \pm 5.08)$ & $(62.5 \pm 7.65)$ & $(43.3 \pm 9.06)$ & $(44.0 \pm 3.93)$ \\
& 6 & 0 & 3 & 9 \\
Checking the body & $(3.77 \pm 1.51)$ & & $(10.0 \pm 5.47)$ & $(5.6 \pm 1.82)$ \\
& 74 & 35 & 20 & 129 \\
Frequent washing & $(83.1 \pm 3.97)$ & $(87.5 \pm 5.22)$ & $(66.6 \pm 8.61)$ & $(81.1 \pm 3.1)$ \\
& 12 & 6 & 6 & 24 \\
& $(13.4 \pm 3.6)$ & $(15.0 \pm 5.64)$ & $(20.0 \pm 7.3)$ & $(15.0 \pm 2.83)$ \\
\hline
\end{tabular}

university students and $53.3 \pm 8.25 \%$ of the secondary school students) and the Western Blot test $(32.5 \pm 4.96 \%$ of the foresters; $17.5 \pm 6.0 \%$ of the university students and $13.3 \pm 6.19 \%$ of the secondary school students). It is worth mentioning that $1 / 10$ of the respondents $(6.7 \pm 2.64 \%$ of the foresters; $12.5 \pm 5.22 \%$ of the university students and $13.3 \pm 6.19 \%$ of the secondary school students) knew that the PCR method was also a diagnostic tool for detecting Lyme disease. Over half of the secondary school students $(53.3 \pm 8.25 \%)$ acknowledged that the blood cell count was the best diagnostic method, whereas for the group of the foresters $(43.8 \pm 5.25 \%)$ and the university students $(62.5 \pm 7.65 \%)$ it was the ELISA test. In the second place, the university students chose the blood cell count test with acidophil cell measurement $(27.5 \pm 7.06 \%)$, and the foresters - the Western Blot test $(32.5 \pm 4.96 \%)$. Statistically significant differences $(p<0.05)$ were observed when comparing the foresters with the university students and the secondary school students, as well as the university students with the secondary school students who would rather perform the ELISA test in order to diagnose Lyme disease $(t=2.0155$, $t=2.1958$, and $t=3.6068$, respectively). The Student's t-test demonstrated that there were statistically significant differences between the university students and the secondary school students $(\mathrm{t}=2.3769 ; \mathrm{p}<0.05)$, the foresters and the secondary school students $(\mathrm{t}=3.3031$; $\mathrm{p}<0.01$ ), who chose the blood cell count test, and also, what was evident, between the foresters and the secondary school students who would perform the Western Blot test $(\mathrm{t}=2.4205 ; \mathrm{p}<0.02)$. All foresters and university students as well as $90.0( \pm 5.47) \%$ secondary school students knew that diagnostic examinations required blood collection. Only $1 / 6(16.6 \pm 6.79 \%)$ of the secondary school students reported that the urine and cerebrospinal fluid, as well as oral cavity rinsing $(3.3 \pm 3.27 \%)$ could be used as the material that could be used to diagnose the disease.

The majority of the foresters $(87.6 \pm 3.49 \%)$ and the university students $(85.0 \pm 5.63 \%)$ had had examinations performed for Lyme disease, whereas $80.0( \pm 7.30) \%$ of the secondary school students had never been subjected to any diagnostic tests. Statistically significant differences were noted $(p<0.001)$ when comparing the foresters with 
Table 7. Frequency and time of Lyme disease examinations

\begin{tabular}{|c|c|c|c|c|}
\hline \multirow{2}{*}{ Frequency and time } & \multicolumn{4}{|c|}{$\begin{array}{l}\text { Respondents } \\
\mathrm{n}(\% \pm \mathrm{SD})\end{array}$} \\
\hline & national forest staff & university students & $\begin{array}{l}\text { secondary school } \\
\text { students }\end{array}$ & total \\
\hline \multicolumn{5}{|l|}{ Frequency } \\
\hline every 6 months & $\begin{array}{c}2 \\
(2.2 \pm 1.55)\end{array}$ & 0 & $\begin{array}{c}4 \\
(13.3 \pm 6.19)\end{array}$ & $\begin{array}{c}6 \\
(3.7 \pm 1.49)\end{array}$ \\
\hline once a year & $\begin{array}{c}53 \\
(59.5 \pm 5.19)\end{array}$ & $\begin{array}{c}29 \\
(72.5 \pm 7.06)\end{array}$ & $\begin{array}{c}7 \\
(23.3 \pm 7.72)\end{array}$ & $\begin{array}{c}89 \\
(55.9 \pm 3.95)\end{array}$ \\
\hline every 2 years & $\begin{array}{c}27 \\
(30.3 \pm 4.87)\end{array}$ & $\begin{array}{c}8 \\
(20.0 \pm 6.32)\end{array}$ & $\begin{array}{c}6 \\
(20.0 \pm 7.30)\end{array}$ & $\begin{array}{c}41 \\
(25.7 \pm 3.46)\end{array}$ \\
\hline every 3 years & $\begin{array}{c}7 \\
(7.8 \pm 2.84)\end{array}$ & $\begin{array}{c}3 \\
(7.5 \pm 4.16)\end{array}$ & 0 & $\begin{array}{c}10 \\
(6.2 \pm 1.91)\end{array}$ \\
\hline don't know & 0 & 0 & $\begin{array}{c}13 \\
(43.3 \pm 9.04)\end{array}$ & $\begin{array}{c}13 \\
(8.17 \pm 2.17)\end{array}$ \\
\hline \multicolumn{5}{|l|}{ Time } \\
\hline on the day of the bite & $\begin{array}{c}6 \\
(3.77 \pm 1.51)\end{array}$ & $\begin{array}{c}5 \\
(12.5 \pm 5.22)\end{array}$ & $\begin{array}{c}5 \\
(16.6 \pm 6.79)\end{array}$ & $\begin{array}{c}16 \\
(10.0 \pm 2.37)\end{array}$ \\
\hline after week & $\begin{array}{c}20 \\
(22.4 \pm 4.41)\end{array}$ & $\begin{array}{c}11 \\
(27.5 \pm 7.06)\end{array}$ & $\begin{array}{c}13 \\
(43.3 \pm 9.04)\end{array}$ & $\begin{array}{c}44 \\
(30.8 \pm 3.66)\end{array}$ \\
\hline after 3-4 weeks & $\begin{array}{c}39 \\
(43.8 \pm 5.25)\end{array}$ & $\begin{array}{c}20 \\
(50.0 \pm 7.9)\end{array}$ & $\begin{array}{c}6 \\
(20.0 \pm 7.3)\end{array}$ & $\begin{array}{c}65 \\
(40.8 \pm 3.89)\end{array}$ \\
\hline after 8 weeks & $\begin{array}{c}24 \\
(26.9 \pm 4.7)\end{array}$ & $\begin{array}{c}7 \\
(17.5 \pm 6.0)\end{array}$ & $\begin{array}{c}6 \\
(20.0 \pm 7.3)\end{array}$ & $\begin{array}{c}37 \\
(23.2 \pm 3.34)\end{array}$ \\
\hline
\end{tabular}

the university students, and the university students with the secondary school students who had undergone diagnostic tests $(\mathrm{t}=10.4559$ and $\mathrm{t}=8.5689)$.

According to $59.9( \pm 5.19) \%$ foresters, and $72.5( \pm 7.06) \%$ university students, the examination for Lyme disease should be done once a year, while $30.0( \pm 4.16) \%$ of the foresters and $20.0( \pm 6.32) \%$ of the university students thought that it was due every second year. Nearly $1 / 2$ of the secondary school students $(43.3 \pm 9.04 \%)$ did not know how often such examination should be carried out (Table 7).

Statistically significant differences $(p<0.001)$ were observed while comparing the foresters with the secondary school students, and the university students with the secondary school students, in whose opinion prophylactic examinations for Lyme disease should be done once a year $(\mathrm{t}=3.8913 ; \mathrm{t}=4.7030$, respectively $)$.

Nearly $1 / 2$ of the university students $(43.8 \pm 5.25 \%)$ and $1 / 2$ of the foresters $(50.0 \pm 7.9 \%)$ responded that the examination should be performed 3-4 weeks after a tick bite, whereas less than $1 / 2$ of the secondary school students $(43.3 \pm 9.04 \%)$ thought that it could be done as early as after 1 week. Only 1/10 (10.0.土 2.37\%) of all respondents would have the examination done on the day of the bite; the precise data are given in Table 7. It was shown (by using the Student's t-test) that there were statistically significant differences between the foresters and the secondary school students ( $\mathrm{t}=2.6468 ; \mathrm{p}<0.02)$, and the university students and the secondary school students $(t=3.3364 ; \mathrm{p}<0.01)$ who would have the examination performed $3-4$ weeks after 
a tick bite. Moreover, the statistical difference $(\mathrm{t}=2.0778$; $\mathrm{p}<0.05$ ) was revealed by comparing the foresters with the secondary school students.

As results from the analysis of obtained data, nearly $2 / 3$ of the respondents, $62.8( \pm 3.83) \%$, would present to a family physician with some alarming symptoms, and $50.9( \pm 3.96) \%$ to a specialist in infectious diseases. Approximately $11 \%$ of the subjects surveyed thought they should report to an occupational health and safety officer. The statistically significant difference $(p<0.05)$ was calculated by comparing the university students with the secondary school students who would present with their problem to an occupational health and safety officer $(\mathrm{t}=2.0737)$.

The majority of the foresters $(89.9 \pm 3.2 \%)$, university students $(95.0 \pm 3.44 \%)$, and secondary school students $(83.3 \pm 6.8 \%)$ stated that Lyme disease was an occupational disease; $8.8( \pm 2.24) \%$ of all the respondents did not respond to this question.

Assessing their knowledge on Lyme disease, $44.9( \pm 5.27) \%$ foresters, $52.5( \pm 7.89) \%$ university students, and $36.6( \pm 8.79) \%$ secondary school students thought that they knew little on this subject and had some doubts as regards the disease. According to $34.8( \pm 5.04) \%$ of the foresters, $42.5( \pm 7.81) \%$ of the university students and $23.3( \pm 7.72) \%$ of the secondary school students, the scope of their knowledge was satisfactory. Please note that approximately $40 \%$ of the secondary school students had very little information on Lyme disease. The Student's t-test showed that there were statistically significant differences between the foresters and the university students $(\mathrm{t}=3.3854$; $\mathrm{p}<0.01)$, the foresters and the secondary school students $(\mathrm{t}=2.4424$; $\mathrm{p}<0.05)$, and the university students and the secondary school students $(\mathrm{t}=4.0017$; $<<0.01)$, whose knowledge on Lyme disease was poor. Over $1 / 2$ of the respondents $(53.4 \pm 3.94 \%)$ had gaps in their knowledge on Lyme disease diagnostics concerning symptoms $(38.9 \pm 3.89 \%)$ and prophylaxis $(28.9 \pm 3.59 \%)$. As results from the data, more than half of the foresters $(51.6 \pm 5.29 \%)$ and the university students $(67.5 \pm 7.4 \%)$ knew very little on the disease diagnostics, as well as on its symptoms $(33.7 \%$ of the foresters and $45 \%$ of the university students). The secondary school students revealed the least knowledge on prophylactic measures $(50.0 \pm 9.12 \%)$ and the symptoms $(46.6 \pm 9.10 \%)$. The comparison of the results obtained for particular groups revealed that there were statistically significant differences between the foresters and the secondary school students $(t=2.3442 ; \mathrm{p}<0.05)$, and the university students and the secondary school students $(\mathrm{t}=23.0181 ; \mathrm{p}<0.02)$ who had gaps in their knowledge on disease source; as well as between the university students and the secondary school students who had little knowledge on the disease prophylaxis $(\mathrm{t}=2.8429$; $\mathrm{p}<0.001)$.

According to $56.1( \pm 5.26) \%$ of the foresters, $50.0( \pm 9.04) \%$ of the university students, and $56.6( \pm 9.04) \%$ of the secondary school students, short talks carried out by medical staff were the best form of education on infectious diseases and their prevention. In the group of the university students $(32.5 \pm 7.4 \%)$, and the secondary school students $(33.3 \pm 8.6 \%)$, leaflets available in outpatient departments were thought to be sufficient in patients' prophylaxis and education. The internet was also a good means of spreading the knowledge in the opinion of $25.8( \pm 3.47) \%$ of all the respondents.

\section{DISCUSSION}

Place of living, working, or learning, and the knowledge on current health risks and methods of their prevention affect the state of our health as well as the frequency of health problems.

Lyme disease is one of numerous infectious diseases resulting from the infection with the spirochete Borrelia burgdorferi, a Gram-negative bacterium [4]. Only 16\% of 
the interviewed subjects knew about this fact; $18 \%$ thought that Lyme disease was caused by a virus.

Lyme disease is a zoonosis; its incidence is inherently associated with a tick bite. A total of $98 \%$ of the respondents rightly regarded it as a main mechanism of infection. The disease cannot be contracted through ingestion of infected meat, although $13 \%$ of the subjects thought that it was possible. The alimentary mechanism of infection is characteristic of parasites such as trichina or tapeworms. Furthermore, ingestion of unwashed fruit contaminated with animal excrements does not lead to the development of Lyme disease as was stated by $6 \%$ of the secondary school students from the Forest Technical Secondary School; this route of infection occurs in case of e.g. human ascaris.

The main route of the spirochete Borrelia burgdorferi transmission in the organism is the blood [4,5], the fact which the majority of the subjects were familiar with (90-100\%). Only a small group of the foresters (4\%) and the secondary school students (10\%) considered the alimentary track as a route of the infection, although occasionally the bacterium may be contracted after ingestion of non-boiled goat, sheep or cow milk from an infected animal. All interviewed subjects responded that Lyme disease could not be transmitted through contact with the infected person.

A tick is both pathogen vector and reservoir for pathogen, which was reported by $55 \%$ of the interviewed subjects. The tick plays an important role in the phylum Arthropoda. The literature data report that some species of flies, fleas, and mosquitoes may transmit Lyme disease, however, their organisms cannot create proper conditions for spirochete development, and thus their significance as reservoir and vector is limited [6-8]. The respondents attribute a considerable role to deer as a reservoir of spirochete (44\% of the interviewed subjects).

Stags, deer, elks are main hoofed mammals the infected adult forms of Ixodes ricinus feed on. Please note that only $9 \%$ of the respondents treated rodents as a reservoir of the bacteria. Vole and mouse families are the main hosts for tick larvae and nymphs. Moreover, numerous ecological studies have confirmed the fact that some bird species (sparrow, blackbird, cormorant) are also a reservoir of the pathogen [9]. Among the respondents, 11\% agreed with this information.

Lyme disease is a growing epidemiological health problem in Poland. The results of the present study indicate that, according to $80 \%$ of the respondents, the incidence rate of this disease increases from year to year, which has been confirmed by the National Hygiene Department [10]. Lyme disease incidence is associated with the presence of natural foci, in which the bacterium circles independently of the humans in a population of neutral hosts and vectors. In the case of Lyme disease, infections have favourable conditions for development due to a high percentage of forested areas, the presence of numerous tourist and holiday centres, as well as propagation of healthy lifestyle. The endemic areas are those in which the percentage of the infected ticks is quite high $[4,11,12]$.

In 2008, the National Hygiene Department considered provinces with the highest disease incidence as endemic, i.e.: Podlasie (82.1/100 000), Warmia and Mazury (42.7/100 000), Silesia (32.1/100 000), Małopolska (31.8/100 000), Podkarpacie (31.5/100 000) [10]. The respondents correctly regarded Podlasie and Warmia and Mazury Provinces as the regions with the highest risk; however, none of the interviewed subjects mentioned the Małopolska Province.

Clinically, Lyme disease is a multisystemic disease inducing numerous dermatological, cardiac, neurological and arthral pathologies [13-16].

The respondents thought fever (65\%) was the first symptom of Lyme disease, followed by painful rash $(33 \%)$ in the form of erythema migrans which, according to the foresters and the university students, lasted for 2-4 weeks, whereas in the opinion of the secondary school students those symptom persisted only for 1 week. The literature data reveal that in $50-80 \%$ of the infected patients, skin 
lesions (erythema migrans) are the first symptoms of the disease, while fever only rarely accompanies the lesions $[4,12]$. The respondents reported myalgia (74\%), arthritis (64\%), rheumatoid changes (41\%), myocarditis (28\%) as other symptoms of Lyme disease. These symptoms are characteristic of disseminated and late stage of the disease, which has been confirmed by the literature data $[12,16]$. In the opinion of $7 \%$ of the interviewed subjects, dyspnoea is also a symptom of the disease. It results from severe lesions of the atrio-ventricular block $[12,16]$. According to $10-11 \%$ of the respondents, vomiting and nausea were the symptoms of Lyme disease; actually, however, they are rarely observed and appear only in association with cerebrospinal meningitis. Additionally, lesions in the nervous system cause sleeping problems in the form of excessive hypersomnia, which was mentioned by $20 \%$ of the respondents $[12,16,17]$. There is a relationship between the exposure to a tick bite and the prevalence of some Lyme disease symptoms, particularly associated with the involvement of the locomotor system [17].

Lyme disease does not belong to diseases with a typical course. It cannot be diagnosed from clinical signs and symptoms only. Testing should be used to support the diagnosis. Among the respondents, $70 \%$ had had the tests for tick-borne spirochaetosis done, and the participation of the secondary school students was lowest. The study by Gałęziowska [18] revealed that more than half $(53.3 \%)$ of her subjects had had the test done on their own initiative, and only $18.3 \%$ on the doctor's recommendation.

Laboratory tests require blood to detect Lyme disease according to $98 \%$ of the interviewed subjects $[4,12,19,20]$. Only $10 \%$ of the subjects know that cerebrospinal fluid can be also collected and 3\% know about the urine test. Other studies $[16,17]$ report that the intra-articular fluid, anterior chamber fluid of the eye, and tissue bioptates may be additionally used for tests. The greatest number of the respondents is familiar with the fact that the examinations are carried out with the ELISA and Western Blot tests; these are the most common and the cheapest diagnostic methods basing on detection of M- and G-class antibodies. Serological test may be performed 3-4 weeks after a tick bite; $40 \%$ of the subjects answered to the question correctly. This time span is associated with the mechanism of producing antibodies in the human organism. IgM appear as early as 3 to 4 weeks after the bite and achieve their peak between the 6th and the 8th week. Test performance after 8 weeks is not correct. The test reliability is higher when 4-6 weeks following the infection, the second class of $\mathrm{G}$ antibodies are produced [19-21].

Performance of diagnostic assays using serological tests is very important for detection of the disease because, according to Chmielewski [22], $\mathrm{M}$ and $\mathrm{G}$ antibodies have been found to be present in 11-13\% of the Polish population, although the subjects examined have not shown visible clinical signs or symptoms of Lyme disease. Dybowska [23] reports that the presence of antibodies against tickborne spirochaetosis has been found in $60-70 \%$ of the foresters in the region of Białowieża, $71 \%$ of the foresters in Karkonosze Mountains, 23\% in the vicinity of Lublin city, and $33 \%$ in the Kujawy and Pomerania Province. This fact confirms that the list of registered Lyme disease cases in Poland does not correlate with the actual number of infected foresters. In other European countries, proportions of the presence of circulating antibodies are different, e.g. they are observed in $23 \%$ of foresters in Slovenia and $7.8 \%$ in Italy [24].

Our own study shows that only $10 \%$ of the respondents know the usefulness of the PCR method to detect Lyme disease. However, due to methodology impediments and a frequent change in the bacterial DNA sequence, this method is not commonly used [19]. A blood cell count in the course of Lyme disease does not show significant deviations from normal values, although sometimes the number of eosinophil cells may be higher. This is a manifestation of an inflammatory process; however, $30 \%$ of the respondents think that this is the sign of the disease. 
A principle assumed to be valid in medicine says that prevention has a priority over treatment. The majority of the interviewed subjects correctly agreed that wearing protective shoes and clothes, using insect or tick repellents, precise checking the entire surface of the skin, paying attention to sites at highest risk at least once a day, and removing ticks within the first hours after a bite represent reasonable preventive measures against tick-borne spirochaetosis infection. The literature data also confirm the effectiveness of these preventive measures [17].

In case of a tick-bite, the greatest number of the respondents will report to the family physician, or the infectious diseases specialist, especially when they observe some alarming symptoms. In the study by Gałęziowska [18], $68.3 \%$ of the interviewed subjects visited doctors providing their services on commercial basis. although they were entitled to free-of-charge health services under the insurance system and only $28.3 \%$ of them were examined by infectious disease specialists. In the respondents' opinion, this was due to insufficient knowledge of the insurancesystem medical staff on Lyme disease (86.6\%), also to physicians' dismissive attitude towards patients (80\%), and to difficulties with the availability of diagnostic tools and treatment.

Health education is a process that promotes knowledge on health and provides counselling on risk factors. These measures are undertaken to increase people's responsibility for their well-being and health and to mobilize their effort for health enhancement. Considering Lyme disease in this aspect, it should be remembered that $45 \%$ of all respondents still know too little and have some doubts as regards this disease. Only $5 \%$ reported that they knew everything on this subject. Please note that approximately $40 \%$ of the secondary school students thought they knew very little on Lyme disease. Thus, this is the group prophylactic and educational programs should be directed at.

The aspects where the knowledge in the majority of the interviewed subjects was insufficient included in the first place diagnostics (53\%), information on disease symptoms $(39 \%)$, and prophylactic measures $(29 \%)$. In the opinion of $55 \%$ of the respondents, talks by the medical staff are the best way to successfully propagate the knowledge. The analysis of our study results indicates the necessity of undertaking educational actions concerning tick transmitted diseases in the groups of employees most frequently faced with the risk of the infection, i.e. foresters. These actions should be aimed at improvement in awareness of Lyme disease prophylaxis, methods for the diagnosis and treatment of the disease. However, until now there has been no educational program targeted at foresters. It was only in 2008 that the Provincial SanitaryEpidemiological Centre and the Polish Society of Health Education, the Division in Białystok, launched an educational program targeted at gymnasium secondary school students entitled "A small or big tick does not bode well". If this appears to be successful, a similar program should be implemented in the future, or the present one should be extended to cover the groups of present and future foresters in order to protect them against tick-borne diseases.

\section{CONCLUSIONS}

Only $15 \%$ of the respondents know the etiological factor of Lyme disease, $98 \%$ know that a tick-bite is the main cause of infection, and that blood is the main route of pathogen transmission. The majority of the subjects are familiar with and abide by prophylactic rules protecting against Lyme disease. The majority of the respondents think that disease incidence rate has increased over the recent years, and that the Podlasie and Warmia and Mazury Provinces have become endemic regions. Propagation of knowledge on Lyme disease, particularly among risk group people is not satisfactory, as approximately $45 \%$ of respondents still know too little about tick-borne spirochaetosis and have some doubts in that respect. 
Secondary school students of the Forest Technical Secondary School should be systematically monitored for Lyme disease infection, because as many as $80 \%$ of them have never had any test done to detect this disease. In health education programmes dealing with Lyme disease, particular attention should be paid to supplying information on the symptoms and diagnosis of the disease. Little knowledge on tick risk among the group of secondary school students indicate the necessity for cooperation between teachers, epidemiologists, and health service providers in order to propagate the knowledge on parasites, symptoms of transmittable diseases, methods of their prevention and spread. According to over half of the respondents, talks carried out by medical professionals informing about Lyme disease and promoting prophylactic measures are the best method of conveying the knowledge on infectious diseases.

\section{REFERENCES}

1. Aucott J, Morrison C, Munoz B, Rowe PC, Schwarzwalder A, West SK. Diagnostic challenges of early Lyme disease: lessons from a community case series. BMC Infectious Diseases 2009;9:1-8.

2. Ogden N.H, Lindsay LR, Morshed M, Sockett, PN, Artsob, H. The emergence of Lyme disease in Canada. Can Med Assoc J 2009;180:1221-4.

3. The Centers for Disease Control and Prevention. Lyme Disease (Borrelia burgdorferi).2008 Case Definition [cited 2010 Jun 20]. Available from URL: http://www.cdc.gov/ncphi/disss/ nndss/casedef/lyme_disease_2008.htm.

4. Shapiro ED, Gerber MA. Lyme Disease. Clin Infect Dis 2000;31:533-42.

5. Gayle A, Ringdahl E. Tick-borne disease. Am Fam Physician 2001;64:461-6.

6. Kosik-Bogacka DI, Kuźna-Grygiel W, Jaborowska M. Ticks and mosquitoes as vectors of Borrelia burgdorferi s.l. in the forested areas of Szczecin. Folia Biol 2007;55:143-6.
7. Magnarelli LA, Anderson JF. Ticks and biting insects infected with the etiologic agent of Lyme disease, Borrelia burgdorferi. J Clin Microbiol 1988;26:1482-6.

8. Zakovska A. Nejedla P, Holikova A, Denis M. Positive findings of Borrelia burgdorferi in Culex (Culex) pipiens pipiens larvae in the surrounding of Brno city determined by the PCR method. Ann Agric Environ Med 2002;9:257-9.

9. Gryczynska A, Zgodka A, Ploski R, Siemiatkowski M. Borrelia burgdorferi sensu lato infection in passerine birds from the Mazurian lake region (Northeastern Poland). Avian Pathol 2004;33:69-75.

10. National Institute of Public Health. National Institute of Hygiene. Department of Epidemiology. Infectious diseases and poisonings in Poland in 2008 [cited 2010 Jun 20]. Available from URL: http://www.pzh.gov.pl/oldpage/epimeld/2008/ Ch_2008.pdf.

11. Steere AC. Lyme disease. N Engl J Med 2001;345:115-25.

12. Bratton RL,Whiteside JW, Hovan MJ, Engle RL, Edwards FD. Diagnosis and Treatment of Lyme Disease. Mayo Clin Proce 2008;83:566-71.

13. Begon E. Aspects articulaires, musculaires, cardiaques et autres manifestations potentielles au cours de la maladie de Lyme. Méd Malad Infect 2007;37:422-34.

14. Depietropaolo D, Powers JH, Gill J.M, Foy AJ. Diagnosis of Lyme disease. Am Fam Physician 2005;72:297-304.

15. Cameron DJ. Clinical trials validate the severity of persistent Lyme disease symptoms. Med Hypotheses 2009;72:153-6.

16. Stanek G, Strle F. Lyme borreliosis. Lancet 2003;362: 1639-47.

17. Kinsley J, Johnson M. Lyme Disease. Knowledge is the best Prevention. Nurse Pract 2004;29(8):34-43.

18. Gałęziowska E. Accessibility of diagnosis and treatment in the opinion of patients suffering from borreliosis [cited 2010 Jun 20]. Available from URL: http://borelioza.gazetka.eu/ artyk/2007-badanie.pdf [in Polish].

19. Aguero-Rosenfeld ME. Laboratory aspects of tick-borne diseases: lyme, granulocytic ehrlichiosis and babesiosis. Mt Sinai J Med 2003;70:197-206. 
20. Hoppa E, Bachur R. Lyme disease update. Curr Opin Pediatr 2007;19:275-80.

21. Buczek A, Rudek A, Bartosik K, Szymanska J, Wojcik-Fatla A. Seroepidemiological study of Lyme borreliosis among forestry workers in southern Poland. Ann Agric Environ Med 2009;16:257-61.

22. Chmielewski T, Tylewska-Wierzbanowska S. Prevalence of Borrelia burgdorferi antibodies in healthy population in Poland. Przegl Epidemiol 2002;56:33-8 [in Polish].
23. Dybowska D, Kozielewicz D, Abdulgater A. Prevalence of borreliosis among forestry workers in Kujawsko-Pomorskie voivodeship. Przegl Epidemiol 2007;61:67-71 [in Polish].

24. Brouqui P, Bacellar F, Baranton G, Birtles RJ, Bjoërsdorff A, Blanco JR, et al. Guidelines for the diagnosis of tickborne bacterial disease in Europe. Clin Microbiol Infect Diseases 2004;10:1108-32.

This work is available in Open Access model and licensed under a Creative Commons Attribution-NonCommercial 3.0 Poland License - http://creativecommons.org/ licenses/by-nc/3.0/pl/deed.en. 